\title{
長期検潮記録を用いた平均水位・潮位 ・長周期波解析
}

\author{
永井紀彦* - 菅原一晃 ${ }^{* *}$ - 渡邊弘 ${ }^{* * *}$ \\ 川口浩二****・三原正裕 ${ }^{* * * * *} \cdot$ 高島勝美
}

\section{1.はじめに}

東京湾口に位置する久里浜検潮所で観測された 1958 年 2 月から 1995 年 12 月までの約 38 年間のデー夕を対 象として，アナログ記録紙上に紙送り速度 $2 \mathrm{~cm} /$ 時間で 記録された波形記録を 1 時間毎に読み取り整理数值化し た. 本研究は, 長期間の検潮記録を基に, 平均水面の経 年変動特性, 調和分解計算結果の変動特性および津波や 気象擾乱に伴う長周期波形記録の解析を, 試みたもので ある。

\section{2. 潮位観測の概要}

久里浜検潮所は, 図一1 に示寸位置(北緯 35 度 13 分 28 秒, 東経 139 度 43 分 27 秒)で行われている。图一2 は, 検潮井戸の断面図・平面図を示したものである. 検潮井 戸は, 内径 $1200 \mathrm{~mm}$, 深さ約 $5 \mathrm{~m}$ であり，導水管は内径 が $131 \mathrm{~mm}$, 長さが地中部 $3.7 \mathrm{~m}$, 海中部約 $4.0 \mathrm{~m}$ となっ ている(佐々木ら, 1979 ; 菅原ら, 1984 ; 菅原ら, 1988). なお, 検潮井戸の周波数応答は, 1996 年イリアンジャ ヤ地震津波の際に, 同じ位置に 1995 年以降に新設された 空中発射型超音波式波高計との比較から, 周期 5 分以上 の長周期波に対しては波形記録は正確であることが，明 らかにされている（小舟ら，1996；永井ら，1996）。

\section{3. 平均水面の変動解析}

\section{1 平均水面の変動}

表一1 は，1958 年 2 月から 1995 年 12 月にかけての観 測デー夕について, 各年ごとの年最高潮位, 朔望平均満 潮位, 平均潮位, 朔望平均干潮位, 年最低潮位, および 各月ごとの平均潮位をまとめた結果である. 表中の年最 高潮位および年最低潮位は, それぞれ, 各年において観 測された潮位の瞬間最高值および最低值である. 年最高 潮位の最大值は, 1979 年の台風 20 号による $313 \mathrm{~cm}$ であ

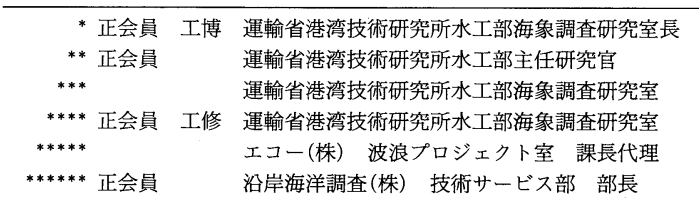

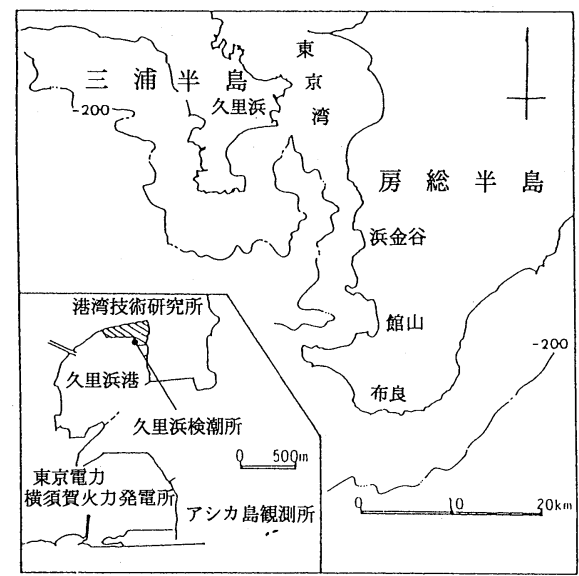

図-1 久里浜湾検潮所位置図

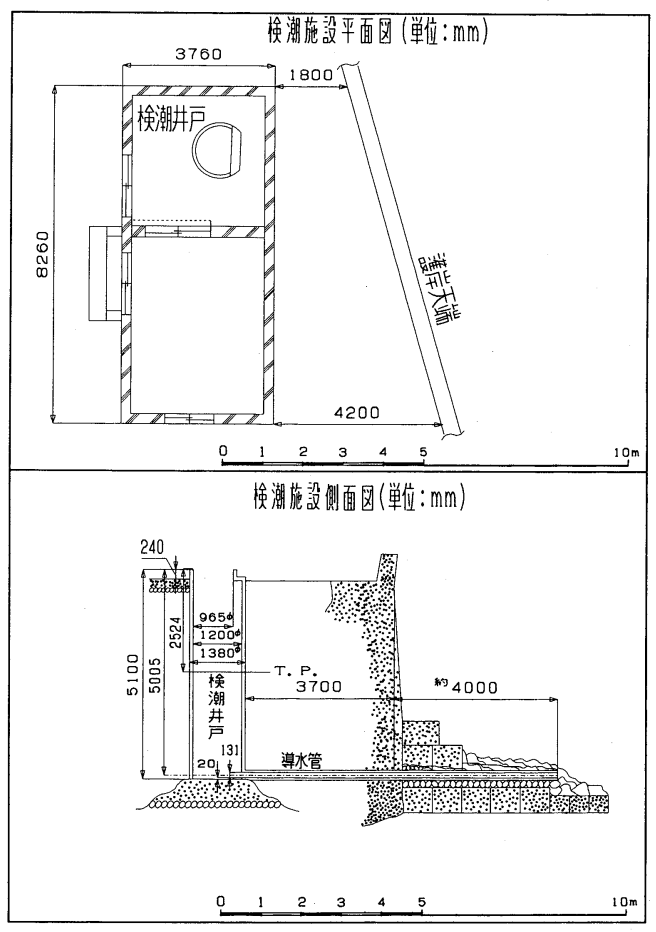

図一2 検潮井戸断面図 - 平面図 
表一1 平均水面等の変動総括表

\begin{tabular}{|c|c|c|c|c|c|c|c|c|c|c|c|c|c|c|c|c|c|}
\hline & \multicolumn{5}{|c|}{ 通 年 值 } & \multicolumn{12}{|c|}{ 月 別平均 值 } \\
\hline & $\begin{array}{l}\text { 年最高潮位 } \\
\text { (H.H.W.L) }\end{array}$ & \begin{tabular}{|c|} 
朔望平均満潮位 \\
(H.W.L)
\end{tabular} & \begin{tabular}{|l} 
平均潮位 \\
(M.S.L)
\end{tabular} & $\begin{array}{c}\text { 朔望平均干潮位 } \\
\text { (L.W.L) }\end{array}$ & \begin{tabular}{|l|} 
年最低潮位 \\
(L.L.W.L.)
\end{tabular} & \begin{tabular}{|l|}
1 月 \\
(JAN.) \\
\end{tabular} & $\begin{array}{c}2 \text { 月 } \\
\text { (FEB.) }\end{array}$ & $\begin{array}{l}\text { 3月 } \\
\text { (MAR.) }\end{array}$ & \begin{tabular}{|c} 
月月 \\
(APLL) \\
\end{tabular} & \begin{tabular}{|c|}
5 月 \\
(MAY.)
\end{tabular} & \begin{tabular}{|c|}
6 月 \\
(JUN.)
\end{tabular} & $\begin{array}{c}7 \text { 月 } \\
\text { (JUL.) }\end{array}$ & \begin{tabular}{|c|}
8 月 \\
(AUG.) \\
\end{tabular} & \begin{tabular}{|c|}
9 月 \\
(SEP.) \\
\end{tabular} & $\begin{array}{l}10 \text { 月 } \\
\text { (OCT.) } \\
\end{array}$ & \begin{tabular}{|l}
$11 月$ \\
(NOV.)
\end{tabular} & \begin{tabular}{|l}
12 月 \\
(DEC.)
\end{tabular} \\
\hline 1958 & 282.0 & $225: 7$ & 161.5 & 72.1 & 47.0 & $\cdots \cdot$ & 161.4 & 160.6 & 154.5 & 164.9 & 161.3 & 155.0 & 149.7 & 148.4 & 173.7 & 176.9 & 170.6 \\
\hline 1959 & 273.0 & 241.6 & 173.8 & 84.4 & 52.0 & 166.8 & 157.3 & 159.4 & 163.4 & \begin{tabular}{|l|}
163.7 \\
\end{tabular} & 180.3 & 182.2 & 182.3 & 185.6 & 186.3 & 179.8 & 178.1 \\
\hline 1960 & 298.0 & 242.8 & 175.9 & 87.3 & 48.0 & 173.4 & 169.9 & 168.0 & 166.5 & 176.0 & 177.5 & 179.0 & 184.4 & 186.5 & 180.2 & 176.9 & \begin{tabular}{|l|l|}
172.9 \\
\end{tabular} \\
\hline 1961 & 262.0 & 238.2 & 175.4 & 86.1 & 61.0 & 170.8 & 170.2 & 167.0 & 163.8 & \begin{tabular}{|l|}
168.0 \\
\end{tabular} & 180.2 & 182.3 & $\mid 190.1$ & 186.1 & $\cdots$ & $\cdots$ & $\cdots$ \\
\hline 1962 & 272.0 & 243.2 & 177.6 & 87.5 & 62.0 & 175.7 & 168.3 & 165.6 & 166.8 & \begin{tabular}{|l|}
72.9 \\
\end{tabular} & 182.9 & 189.1 & 179.7 & 182.8 & 190.6 & 178.7 & 178.2 \\
\hline 963 & 56.0 & 234.8 & 169.5 & 76.4 & 41.0 & 180.0 & 165.0 & 158.2 & 152.4 & 164.8 & 169.0 & 170.8 & 174.7 & 175.5 & 178.6 & 175.5 & 168.8 \\
\hline 1964 & 3.0 & 236.3 & 171.3 & 76.0 & 48.0 & 166.5 & 166.5 & 160.8 & 155.6 & 175.3 & 171.7 & 170.7 & \begin{tabular}{|l|}
177.6 \\
\end{tabular} & \begin{tabular}{|l|l|}
184.7 \\
\end{tabular} & 175.4 & 179.4 & \begin{tabular}{|l|}
171.6 \\
\end{tabular} \\
\hline 1965 & 269.0 & 238.7 & 171.6 & 76.2 & 44.0 & \begin{tabular}{|l|l|}
171.1 \\
\end{tabular} & 164.5 & 163.9 & 158.5 & \begin{tabular}{|l|}
165.6 \\
\end{tabular} & 180.3 & 178.7 & 174.4 & 179.0 & 176.2 & 178.9 & 167.7 \\
\hline 1966 & 265.0 & 239.1 & 173.3 & 76.7 & 42.0 & 170.9 & 166.7 & 167.6 & 171.4 & 163.9 & 172.3 & 172.7 & 182.7 & 182.1 & 180.0 & 173.1 & 176.8 \\
\hline 1967 & 270.0 & 237.4 & 173.7 & 75.8 & 48.0 & 169.9 & 160.4 & \begin{tabular}{|l}
157.1 \\
\end{tabular} & 157.5 & 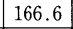 & 180.9 & 186.7 & 182.6 & 190.4 & 181.0 & 177.7 & 173.0 \\
\hline 1968 & 273.0 & 237.2 & 172.0 & 80.0 & 49.0 & 175.5 & 170.0 & 160.7 & 156.6 & 162.4 & 163.9 & 175.8 & \begin{tabular}{|l|l}
191.8 \\
\end{tabular} & 180.9 & 179.8 & 173.1 & 173.4 \\
\hline 1969 & 273.0 & 242.0 & 175.7 & 80.6 & 54.0 & 171.8 & 162.1 & 168.6 & 172.4 & 183.4 & 179.9 & 181.9 & 179.8 & 177.8 & 177.6 & 179.6 & 173.9 \\
\hline 1970 & 266.0 & 238.7 & 173.8 & 77.2 & 47.0 & 174.9 & 172.0 & 166.5 & 160.1 & \begin{tabular}{|l|l}
168.1 \\
\end{tabular} & 172.1 & 172.4 & 174.5 & \begin{tabular}{|l}
179.6 \\
\end{tabular} & 184.0 & 188.1 & \begin{tabular}{|l}
173.5 \\
\end{tabular} \\
\hline 1971 & 272.0 & 241.6 & 175.0 & 78.3 & 54.0 & 181.0 & 168.5 & 166.4 & 160.6 & 165.7 & 176.0 & 180.4 & 188.3 & 193.5 & 184.8 & 170.0 & 164.8 \\
\hline 1972 & 271.0 & 248.9 & 180.9 & 88.1 & 52.0 & 176.5 & 175.6 & 171.7 & 165.4 & 175.3 & 179.9 & 191.0 & 189.6 & \begin{tabular}{|l|l}
192.8 \\
\end{tabular} & 188.3 & 184.4 & 179.8 \\
\hline 1973 & 265.0 & 245.0 & 178.9 & 83.6 & 49.0 & 170.0 & 171.6 & 174.5 & 179.9 & 172.7 & 180.6 & 181.3 & 181.5 & $\mid 184.7$ & 184.9 & 188.5 & 176.6 \\
\hline 1974 & 278.0 & 6.8 & 179.1 & 85.9 & 59.0 & 177.1 & 173.0 & 168.4 & 170.5 & \begin{tabular}{|l|}
775.2 \\
\end{tabular} & \begin{tabular}{|l|l|} 
\\
\end{tabular} & 182.6 & \begin{tabular}{|l}
183.4 \\
\end{tabular} & 191.3 & 186.2 & 176.3 & 177.5 \\
\hline 975 & 289.0 & 247.2 & 181.9 & 91.4 & 66.0 & 180.3 & 178.0 & 169.9 & 167.8 & 174.4 & 178.7 & 182.5 & 193.7 & \begin{tabular}{|l|l|}
196.0 \\
\end{tabular} & 190.7 & 185.6 & 185.5 \\
\hline 1976 & 272.0 & 250.4 & 184.0 & 94.6 & 67.0 & 179.6 & \begin{tabular}{|l|l} 
\\
\end{tabular} & \begin{tabular}{|l|l}
173.8 \\
\end{tabular} & 177.5 & 182.8 & 187.4 & 185.9 & 188.5 & 196.9 & 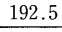 & 185.1 & 180.6 \\
\hline 1977 & 270.0 & 245.1 & 181.5 & 91.6 & 60.0 & 177.3 & 175.9 & 171.2 & 172.4 & 175.5 & 185.4 & 183.1 & 189.1 & 191.3 & 187.9 & 183.6 & 184.8 \\
\hline 1978 & 276.0 & 250.9 & 184.0 & 93.6 & 65.0 & 182.5 & 178.4 & \begin{tabular}{|l|l}
176.5 \\
\end{tabular} & 178.9 & 178.3 & 180.8 & 191.1 & \begin{tabular}{|l}
193.5 \\
\end{tabular} & \begin{tabular}{|l|l|l}
192.8 \\
\end{tabular} & 190.3 & 185.6 & 179.5 \\
\hline 1979 & 313.0 & 253.0 & 184.3 & 95.6 & 62.0 & 176.0 & 178.4 & 179.5 & 175.8 & 179.6 & 183.9 & 193.9 & 188.0 & \begin{tabular}{|l|l|}
191.6 \\
\end{tabular} & 194.1 & 185.1 & 185.8 \\
\hline 1980 & 288.0 & 249.3 & 182.4 & 91.1 & 63.0 & 186.3 & 169.4 & \begin{tabular}{|l|l}
172.3 \\
\end{tabular} & 169.6 & 181.9 & 178.8 & 186.6 & 186.9 & \begin{tabular}{|l|l|} 
\\
\end{tabular} & 189.7 & 187.4 & \begin{tabular}{|l|l}
191.6 \\
\end{tabular} \\
\hline 1981 & 261.0 & 244.1 & 178.7 & 84.2 & 67.0 & 180.1 & \begin{tabular}{|l}
76.9 \\
\end{tabular} & 168.8 & 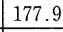 & 177.9 & 186.2 & & & 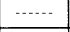 & & \begin{tabular}{|l|l|} 
\\
\end{tabular} & 179.9 \\
\hline 1982 & 281.0 & 246.4 & 182.0 & 89.1 & 57.0 & 177.7 & 170.2 & $\mid 168.9$ & 175.3 & 184.8 & 187.2 & 181.7 & 190.6 & \begin{tabular}{|l|}
193.1 \\
\end{tabular} & 193.8 & 181.0 & 180.2 \\
\hline$\underline{1983}$ & 279.0 & 48.9 & 184.6 & 1.1 & .0 & 176.2 & 177.3 & 175.0 & 171.1 & 182.4 & 190.3 & 194.9 & 95.5 & 193.2 & 187.3 & 187.1 & 185.1 \\
\hline 1984 & 272.0 & 4.5 & .3 & 36.5 & 61.0 & 177.4 & 173.9 & 169.9 & 167.9 & 171.5 & 188.6 & 182.8 & 180.9 & \begin{tabular}{|l|l|} 
\\
\end{tabular} & 196.0 & 186.4 & 182.7 \\
\hline 1985 & 281.0 & 44.1 & 178.5 & 82.8 & 59.0 & \begin{tabular}{|l|l|} 
\\
\end{tabular} & 171.6 & \begin{tabular}{|l|l}
163.1 \\
\end{tabular} & 169.3 & \begin{tabular}{|l|}
173.8 \\
\end{tabular} & 186.6 & 189.6 & 180.6 & \begin{tabular}{|l|l|}
182.7 \\
\end{tabular} & 188.7 & 190.4 & 175.2 \\
\hline 1986 & 266.0 & 45.6 & 179.8 & 82.8 & 55.0 & 175.2 & 175.4 & 177.3 & 170.4 & 173.0 & 176.8 & 182.9 & 185.5 & 189.2 & 183.8 & 180.0 & 187.6 \\
\hline 1987 & 264.0 & 246.9 & 181.7 & 87.3 & 62.0 & 155.4 & 179.1 & 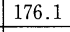 & 174.0 & 182.6 & 185.9 & 189.2 & 191.7 & \begin{tabular}{|l|}
194.6 \\
\end{tabular} & 186.2 & 183.4 & 182.7 \\
\hline 1988 & 273.0 & 250.2 & 183.9 & 87.3 & 50.0 & 177.8 & 178.5 & 177.3 & 182.0 & 183.5 & 186.1 & $\mid 188.6$ & 184.5 & 191.5 & \begin{tabular}{|l|l} 
\\
\end{tabular} & 187.0 & 174.6 \\
\hline 1989 & 272.0 & 246.4 & 180.8 & 84.8 & 55.0 & 172.3 & 169.5 & 172.0 & 170.6 & 181.6 & 180.4 & 185.3 & 190.3 & \begin{tabular}{|l|l|}
186.3 \\
\end{tabular} & 185.8 & 185.0 & $\mid 191.1$ \\
\hline 1990 & 295.0 & 252.0 & 185.3 & 88.3 & 47.0 & 181.0 & 168.6 & 177.5 & 182.9 & 176.3 & \begin{tabular}{|l|l|} 
\\
\end{tabular} & 192.6 & 199.5 & \begin{tabular}{|l|l|}
196.2 \\
\end{tabular} & \begin{tabular}{|l|l} 
\\
\end{tabular} & 188.3 & 179.8 \\
\hline 1991 & 277.0 & 253.6 & 186.3 & 89.7 & 57.0 & 185.9 & 180.1 & 182.2 & 173.3 & 178.0 & 182.2 & 189.3 & 199.0 & 192.2 & 197.4 & 189.7 & 185.9 \\
\hline 1992 & 272.0 & 252.7 & 187.3 & 93.6 & 62.0 & 185.0 & \begin{tabular}{|l|l|}
181.6 \\
\end{tabular} & 179.4 & 189.0 & 187.5 & 189.2 & 188.7 & 184.5 & \begin{tabular}{|l|l|}
194.3 \\
\end{tabular} & 200.4 & 185.0 & 183.5 \\
\hline$\underline{1993}$ & 276.0 & 52.9 & 84.6 & 91.0 & 71.0 & 182.5 & 180.3 & 182.6 & 185.0 & 180.9 & 181.0 & 184.0 & 191.3 & \begin{tabular}{|l|l|}
191.9 \\
\end{tabular} & 194.5 & 180.0 & 181.8 \\
\hline 1994 & 267.0 & 251.2 & 186.9 & 97.2 & 69.0 & 188.3 & \begin{tabular}{|l|l}
184.9 \\
\end{tabular} & $\mid 175.9$ & 184.1 & 182.8 & 187.5 & 192.6 & 189.2 & \begin{tabular}{|l|l|}
197.9 \\
\end{tabular} & 191.8 & 182.7 & 184.9 \\
\hline 1995 & 286.0 & 254.6 & 188.8 & 97.8 & 74.0 & 185.2 & 184.1 & 178.4 & 183.9 & 189.2 & 192.9 & $\mid 191.7$ & 187.6 & 192.9 & 193.0 & 195.6 & 191.5 \\
\hline
\end{tabular}

り,これに次ぐ值は 1960 年チリ地震津波による $298 \mathrm{~cm}$ であった。

図-3 は, 表一 1 中の年最高潮位, 朔望平均満潮位, 平 均潮位, 朔望平均干潮位, 年最低潮位の経年変化を示し たものであり, 図-4 は, 月平均潮位の変化を, より詳細 に示したものである.月平均潮位は，季節によって変動 し, 夏は平均潮位が高く, 冬は低いことがわかる。こう

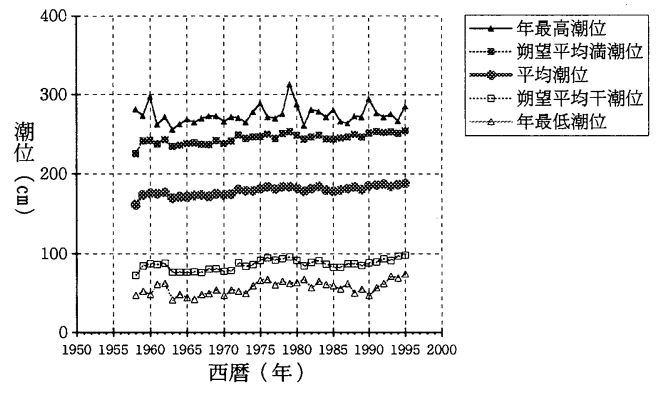

図一3 潮位の経年変動
した季節変動に加えて, 最小自乗法による回㷌直線が示 すように，長期的に平均潮位は緩やかに上昇している. この長期的な平均潮位の増加量は, 検潮器零位を基準と して, $4.4 \mathrm{~mm} /$ 年である.

\section{2 地盤沈下量の評価}

平均潮位の増加量, すなわち平均水位上昇量を考える 際には, 地盤沈下量を適切に評価することが重要である.

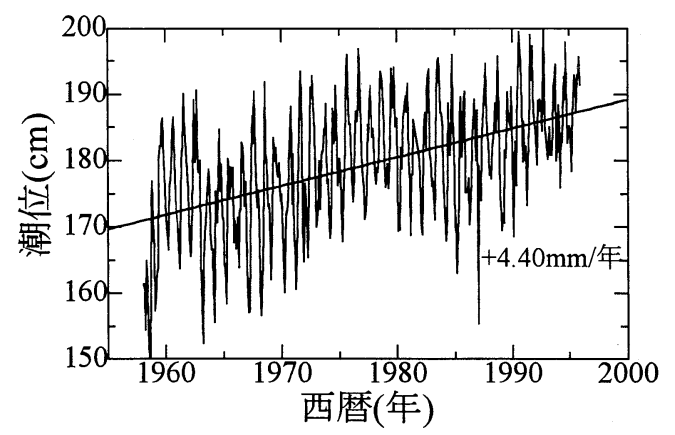

図-4 月平均潮位の変動 
図一 5 は, 検潮器零位の地盤沈下量の評価を試みたも のである.すなわち,近傍の国土地理院第 10845 号一等水 準点と検潮器零位間における 1975 年と 1992 年の 2 回の 測量結果(標高差 $6.0709 \mathrm{~m}$ および $6.0488 \mathrm{~m}$ )を, 1969 年 と 1990 年に発表された同水準点の国土地理院平均成果 （東京湾平均水位を基準として $4.2989 \mathrm{~m}$ および 4.2218 m) の 2 データを直線で結んだ水準点の標高変化直線に つなぎ, 1975 年と 1992 年における検潮器零位の標高を, 東京湾平均水位を基準として，それぞれ, $-1.7940 \mathrm{~m}$ お よびー $1.8343 \mathrm{~m}$ と考え, 検潮器零位の沈下量を 2.37 $\mathrm{mm} /$ 年と推定した.この值を, 図一 4 に示す $4.40 \mathrm{~mm} /$ 年 から差し引くと, 東京湾平均海面を基準とした久里浜検 潮所の水位上昇量は, $2.03 \mathrm{~mm} /$ 年となった。

\section{3 気温変化との関係}

平均水位の上昇問題は, 地球温暖化とあわせて論じら れている. 図一6 は, 気象庁が発表した世界平均気温の年 平均值の上昇データと, 図一 4 および図-5 で考察した平 均水位上昇量との比較検討を試みたものである。

図一6 の左縦軸 (黒丸) は久里浜検潮所における年平均 水位偏差を示したものであり，1958 年から 1995 年まで の平均水位を基準として示している，右縦軸（白丸）は, 気象庁発表の世界平均気温の年平均值の偏差を示してお り, 同じ期間中の最小自乗法による回帰直線の傾きは, + $0.014^{\circ} \mathrm{C} /$ 年であり，上昇傾向を示していた. 図一6では， 平均水位偏差と平均気温偏差の回㷌直線の傾きが共通に

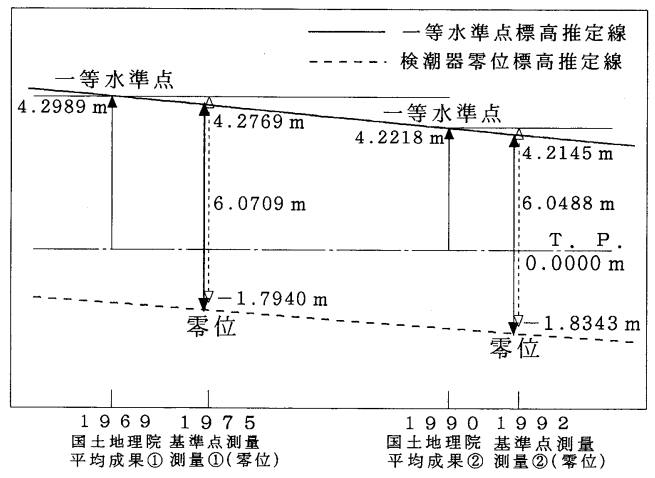

図一5＼cjkstart基準点の地盤沈下量

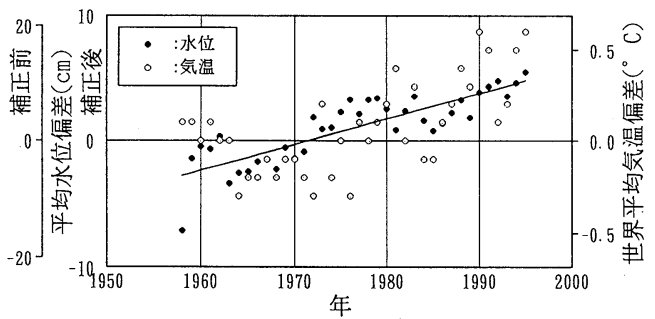

図一6 平均海面の上昇と平均気温
表一2 長周期波の周期と最大両振幅の出現分布

\begin{tabular}{c|c|r|r|r}
\hline \multirow{2}{*}{ 両振幅 $(\mathrm{cm})$} & \multicolumn{2}{|c|}{ 周 } & \multicolumn{2}{|c|}{ 期 } \\
\cline { 2 - 4 } & -10 & $10-20$ & $20-$ & \multirow{2}{*}{ 分) } \\
\hline $15-20$ & 17 & 80 & 0 & 97 \\
$20-25$ & 17 & 22 & 1 & 40 \\
$25-30$ & 12 & 7 & 1 & 20 \\
$30-40$ & 6 & 4 & 0 & 10 \\
$40-50$ & 6 & 1 & 0 & 7 \\
$50-100$ & 5 & 0 & 0 & 5 \\
$100-$ & 0 & 0 & 1 & 1 \\
\hline 合 計 & 63 & 114 & 3 & 180 \\
\hline
\end{tabular}

*範囲は，以上一未満を表す

なるように右縦軸と左縦軸のレンジを調整表示してい る.

平均気温偏差と平均水位偏差のそれぞれの経年変動 は, 必ずしも年毎に一致するわけではないが, ともに 1962 年頃, 1977 年頃, 1990 年頃に極大值を, 1964 年頃と 1985 年頃に極小值を示しているようであり，10 年から 20 年程度の周期で増加減少を繰り返しながらも, 長期的 には増加する傾向を示している. 図一6によれば, 平均気 温が 1 度上昇するのに対応して水位が約 $15 \mathrm{~cm}$ 上昇す ることとなる.この割合は, 西暦 2100 年頃に平均気温が 2 度上昇し海面が $50 \mathrm{~cm}$ 上昇するという IPPC 報告で示 される割合よりも，若干低くなっている (IPCC, 1990； 気象庁, 1993).

\section{4. 長 周期 波}

\section{1 観測された長周期波}

図一7は，長周期波の発生状況を年別および要因別に とりまとめたものである。ここでは長周期波として最大 両振幅が $15 \mathrm{~cm}$ を越えるものを抽出したが， 38 年間で 180 ケース見られた。内訳は，津波の 4 ケースを除いて， 他は気象擾乱に伴うものであった。

表一2 は, 抽出された長周期波の両振幅と, ゼロアップ クロス法によって定義される平均的な周期の, 結合出現



図一7 長周期波の発生状況 




(a)天文潮位成分を除去した記録

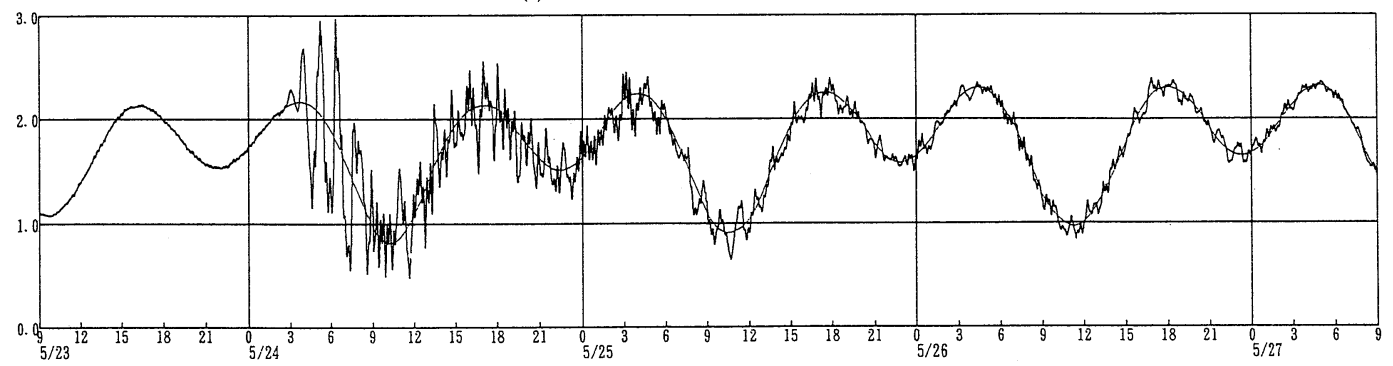

(b)天文潮位成分を含んだ記録

図一8チリ地震津波波形

頻度分布を示したものである. 気象擾乱に伴う長周期波 の周期は, $2-3$ 分 (久里浜湾内の固有周期) のものと, 15 分程度のもの（久里浜・金谷間の固有周期に対応）に 大別された。これに対して,津波の周期は津波毎に異なっ たものであった。

\section{2 チリ地震津波}

観測された長周期波の中で, 最大の振幅と周期を記録 したものが, 1960 年のチリ地震津波によるものであっ た. チリ地震津波は, 約 1 日かかって太平洋を横断し, 我が国太平洋岸に来襲し, 広い範囲で被害を発生させた 津波である。

図一 8 は, 久里浜検潮所におけるチリ地震津波来襲時 の波形記録を示したものである.波形記録は，検潮記録 紙上の記録を細かくデジタイザーで読み取り数值化した が，検潮記録紙の紙送り速度は $2 \mathrm{~cm} /$ 時間であるため, $0.2 \mathrm{~mm}$ 毎に読み取りを行ったので，データのサンプリ ング間隔は 36 秒となった. 下段の罒は, 天文潮位変化を 含めた記録であり, 上段の図は, 下段の図に滑らかな細 線で示される天文潮位成分を除去した津波記録である.

図一9 は，津波波形の周波数スペクトル解析結果を示 したものである、しかしながら，津波のような非定常な 現象に対しては, 解析対象時間と同じ波形が無限回繰り 返されるというスペクトル解析の前提条件が満たされて いないため, スペクトル解析の妥当性と信頼性に関して は, 特に注意が必要となる。
そこで, 解析対象時間を変化させた解析を試みた。 図一8 に示される(1)(2)(3)(4)と(1)'(2)'(3)'(4)'(5)'(6)'(7)'(8)は, それぞれ,データサンプリング時間の設定を示しており, 図一9に示すそれぞれの津波波形の周波数スペクトルに 対応している.サンプリング時間は, (1)は 8192 データ (81 時間 55 分 12 秒間のデータ), (2)は半分の 4096 デー 夕 (40 時間 57 分 36 秒間), (3)はさらに半分の 2048 デー 夕 (20 時間 28 分 48 秒間), (4)はさらに半分の 1024 デー 夕 (10 時間 14 分 24 秒間) であり, (1)から8)までは, そ れぞれ，(1)の期間を 8 分割した 1024 デー夕（10 時間 14

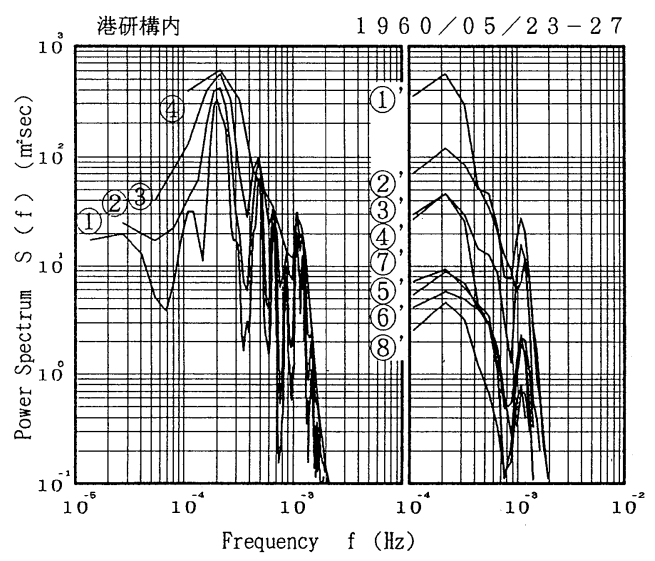

図一9 チリ地震津波のスペクトル 
表一3 主要 4 分潮の振幅の変動

\begin{tabular}{r|r|r|r|r|r}
\hline & $\begin{array}{r}M_{2} \text { 振幅 } \\
(\mathrm{cm})\end{array}$ & \multicolumn{1}{|c|}{$\begin{array}{r}S_{2} \text { 振幅 } \\
(\mathrm{cm}\end{array}$} & $\begin{array}{c}K_{1} \text { 振幅 } \\
(\mathrm{cm})\end{array}$ & $\begin{array}{c}O_{1} \text { 振幅 } \\
(\mathrm{cm})\end{array}$ & \multicolumn{1}{|c}{$\begin{array}{c}Z_{0} \text { 振幅 } \\
(\mathrm{cm})\end{array}$} \\
\hline 最大 年 & 1965 & 1960 & 1986 & 1986 & 1965 \\
振幅 & 36.684 & 17.492 & 23.944 & 19.006 & 96.621 \\
\hline 最小 年 & 1983 & 1983 & 1960 & 1976 & 1976 \\
振幅 & 35.610 & 16.968 & 22.985 & 18.247 & 94.416 \\
\hline 38 年平均 & 36.061 & 17.222 & 23.476 & 18.576 & 95.335 \\
\hline 標準偏差 & 0.268 & 0.110 & 0.204 & 0.168 & 0.492 \\
\hline
\end{tabular}

分 24 秒間）である.

図一9 の左図中で，(4)はもっとも津波の高い期間につ いて計算した結果で，スペクトル全体のパワーが最も高 く, (1)は時間とともに減衰した波形の影響を受けてパ ワーは相対的に低くなっている。しかし，スペクトルの 形状は，4 ケースともよく一致している. 図一9 の右図中 で，(1)一-8'から時間経過とともにスペクトルのパワー の減少が見られるものの，スペクトルの形状はあまり変 化せず, チリ地震津波による水位変動は， 3 日間以上も 継続したことがわかる。

スペクトルのピーク周波数は, $2 \times 10^{-4} \mathrm{~Hz}$ 付近 (83 分) で, 各サンプリング時間に共通している. (1)'-8'の経時 変化に注目すると, 久里浜と対岸の房総半島の金谷間の モードの固有周期に対応する周期約 15 分のピークが, 時 間経過とともに津波のピーク周期に比べて相対的に大き くなっていることがわかる。これらの結果は, チリ地震 津波の周期に関しての文献（高橋ら，1961；HATORI, 1969）をさらに詳細に補足するものである.

\section{5. 調和定数の経年变動}

表一 3 は，各年毎に行った調和分解計算結果を主要 4 分潮の振幅と $Z_{0}$ （主要 4 分潮の振幅の和）の経年変動に ついてとりまとめたものである．表中には，振幅の最大 值, 最小值, 38 年間平均值扔よび変動の標準偏差を, 対 応する観測年とともに示している．4 分潮の振幅の年別 の変動はそれぞれ $2 \%$ 程度の範囲にほぼ収まってい る. $Z_{0}$ の最大值は $M_{2}$ 分潮の振幅が最大值を示した 1965 年に, $Z_{0}$ の最小值は $O_{1}$ 分潮の振幅が最小值を示した 1976 年に見られ，それぞれの值は $96.621 \mathrm{~cm}$ おび $95.335 \mathrm{~cm}$ であった. しかし, 主要 4 分潮以外の分潮に関 しては，周期の長い分潮ほど， 1 年以上の長周期変動の 影響のためと考えられるが，年毎の変動が大きかった.

\section{6. 気象偏差}

表一 4 は, 各年の 28 分潮から計算される天文潮位と毎 正時の観測潮位の偏差の大きい上位 10 個を示したもの である. 4.1 で抽出した長周期波と重なっている気象偏 差は 10 ケース中 6 ケース見られ,太平洋側を台風または
表-4 上位気象偏差一覧

単位: $\mathrm{cm}$

\begin{tabular}{|c|c|c|c|c|c|}
\hline $\begin{array}{l}\text { 順 } \\
\text { 位 }\end{array}$ & $\begin{array}{c}\text { 発 生 期 間 } \\
\text { 年月日時〜年月日時 } \\
\end{array}$ & \begin{tabular}{|c|} 
最大偏差発生時 \\
年 ${ }^{\text {日 時 }}$ \\
\end{tabular} & 最大 & 気象要因 & $\begin{array}{l}\text { 長周期波 } \\
\text { 出 振 幅 }\end{array}$ \\
\hline 1 & $\begin{array}{rll}79 / 10 / 1816 \text { 時〜 } & \\
& 79 / 10 / 20 \quad 2 \text { 時 } \\
\end{array}$ & $79 / 10 / 1916$ 時 & 51 & 台風 7920 & 38.0 \\
\hline 2 & $\begin{array}{|lll|}58 / 7 / 22 & 5 \text { 時〜 } \\
& 58 / 7 / 24 \quad 1 \text { 時 } \\
\end{array}$ & $58 / 7 / 23 \quad 9$ 時 & 47 & 台風 5811 & 90.0 \\
\hline 3 & $\begin{array}{|lll|}82 / 9 / 12 & 6 \text { 時〜 } \\
& 82 / 9 / 13 & 8 \text { 時 } \\
\end{array}$ & $82 / 9 / 1222$ 時 & 42 & 台風 8218 & 45.0 \\
\hline 4 & $\begin{aligned} 70 / 1 / 3017 \text { 時〜 } \\
70 / 2 / 110 \text { 時 } \\
\quad\end{aligned}$ & $70 / 1 / 31 \quad 9$ 時 & 41 & 日本海低気圧 & ...... \\
\hline 5 & \begin{tabular}{|ll|l|}
$85 / 30$ & 7 時〜 \\
& $85 / 7 / 120$ 時
\end{tabular} & $85 / 7 / 13$ 時 & 41 & 台風 8506 & 48.5 \\
\hline 6 & $\begin{aligned} 67 / 9 / 1010 \text { 時〜 } \\
67 / 9 / 1911 \text { 時 }\end{aligned}$ & $67 / 9 / 152$ 時 & 40 & 台風 6722 & …-. \\
\hline 7 & \begin{tabular}{|cc|c|}
$58 / 9 / 18 \quad 2$ 時〜 \\
$58 / 9 / 18 \quad 17$ 時
\end{tabular} & $58 / 9 / 18 \quad 8$ 時 & 38 & 台風 5821 & 60.0 \\
\hline 8 & $\begin{array}{|cc|}59 / 9 / 26 \quad 12 \text { 時〜 } & \\
& 59 / 9 / 27 \quad 19 \text { 時 } \\
\end{array}$ & $59 / 9 / 2623$ 時 & 37 & \begin{tabular}{|c|}
$\begin{array}{c}\text { 台風 } 5915 \\
\text { (伊勢湾台風) }\end{array}$ \\
\end{tabular} & 45.5 \\
\hline 9 & $\begin{array}{|ll|}69 / 8 / 23 \quad \begin{array}{l}5 \text { 時〜 } \\
69 / 8 / 25 \quad 16 \text { 時 }\end{array} \\
\end{array}$ & $69 / 8 / 2315$ 時 & 37 & 台風 6909 & …... \\
\hline 10 & $\begin{array}{|cc|}58 / 12 / 2522 & \text { 時〜 } \\
& 58 / 12 / 27 \quad 19 \text { 時 } \\
\end{array}$ & $58 / 12 / 2616$ 時 & 36 & 日本海低気圧 & ....... \\
\hline
\end{tabular}

低気圧が通ったときに発生している，最大気象偏差は， 1979 年 10 月 17 日から 20 日にかけて太平洋側を通過し

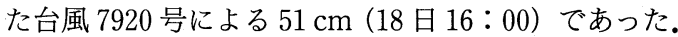

\section{7. おわりに}

本研究は, 東京湾口に位置する久里浜検潮所で観測さ れた 1958 年 2 月から 1995 年 12 月までの約 38 年間の デー夕を対象として，平均水面の経年変動特性，潮位調 和分解計算結果の変動特性, および津波や気象擾乱に伴 う長周期波形記録の解析を，試みたものである.

なお，本研究のとりまとめにあたって，建設省国土地 理院, 海上保安庁水路部, 東北大学首藤伸夫教授から, 御指導をいただいたことを記し，謝意を表する。

\section{参 考 文 献}

気象庁 (1993)：気候変動に関する政府間パネル (IPCC) 科学的 評価 $\sim 1990$ 年報告書・1992 年補遺概要 $\sim, 106 \mathrm{p}$.

小舟浩治・永井紀彦·橋本典明·平石哲也·清水勝義（1996）：1996 年イリアンジャヤ地震津波の特性, 港湾技研資料 No. 842,96 p.

佐々木弘・菅原一晃・佐々木徹也・広瀬宗一・金子大二郎・高橋 智晴・夷塚葉子 (1979): 港研構内およびアシカ島における 気象・海象観測，港湾技研資料 No. 314,130 p.

菅原一晃・立花祐二・佐々木弘・広瀬宗一・橋本典明（1984）：港 研構内およびアシカ島における気象・海象観測その 2, 港湾 技研資料 No. $481,61 \mathrm{p}$.

菅原一晃・成田 明・亀山 豊・小舟浩治・後藤智明・橋本典明 (1988): 港研構内およびアシカ島に扔ける気象・海象観測そ の 3 , 港湾技研資料 No. 624,70 p.

高橋龍太郎・相田 勇 (1961)：津波スペクトルの研究，地震研 究所彙報 Vol. 39, pp. 523-535.

永井紀彦・菅原一晃・渡邊 弘・川口浩二 (1996)：久里浜湾に おける長期検潮記録解析, 港研報告, 第 35 巻, 4 号, 35 p.

HATORI. T (1969): Analyses of Oceanic Long-period Waves at Hachijo Island, 地震研究所彙報 Vol. 47, pp. 863-874.

IPCC WG1 (1990): Policymakers Summary of the Scientific Assessment of Climate Change, $27 \mathrm{p}$. 